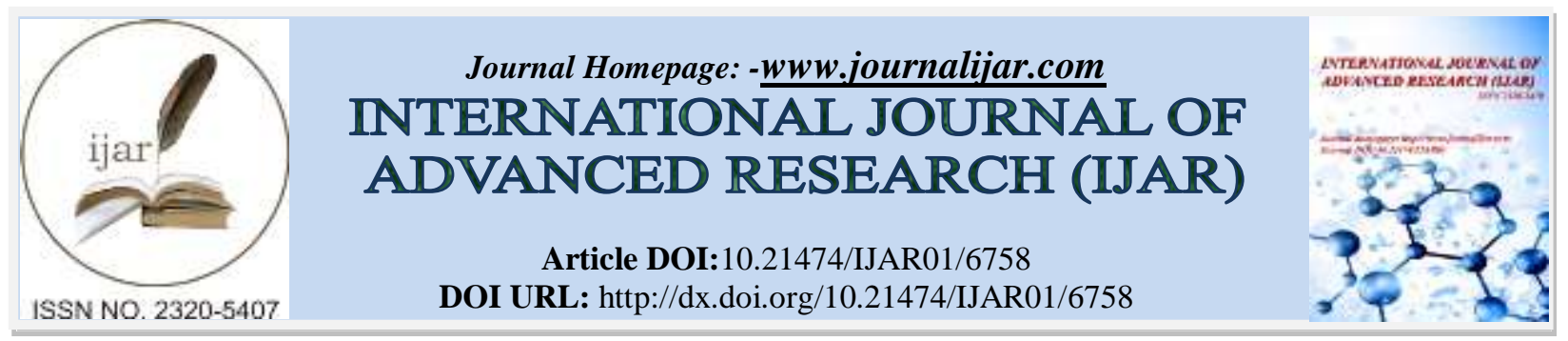

RESEARCH ARTICLE

\title{
VARIATION IN NUTRITIONAL COMPOSITION OF FLOWER BUDS OF CALLIGONUM POLYGONOIDES IN DIFFERENT REGIONS OF THAR DESERT.
}

\begin{abstract}
Mala Rathore.
Non-Wood Forest Products Division Arid Forest Research Institute PO-Krishi Mandi, Pali Road, Jodhpur.

\section{Manuscript Info}

Manuscript History

Received: 16 January 2018

Final Accepted: 18 February 2018

Published: March 2018

Keywords:-

Food supplement, Desert, Sugar, Protein,

Fat, Vitamin C, Minerals, Dietary Fibre

\section{Abstract}

Calligonum polygonoidesis the most common perennial shrub, widely present in some localities of Thar Desert. Flowers are believed to be very nutritious and contain high amount of protein. Nutritional evaluation of flower buds from different regions of Rajasthan was taken up so as to determine the superior chemotype in terms of its food value. There are few reports on nutrional value of Calligonum polygonoides but its variation from different areas has not been studied. Moisture, fat, sugar, protein, vitamin $\mathrm{C}$ content alongwith mineral analysis was done. The average nutritional content in case of Calligonum polygonoides was as follows: ash11.14 \%, DF $44.98 \%$, fat $1.27 \%$, sugar $9.75 \%$, protein $8.02 \%$ and vitamin C $66.88 \mathrm{mg} / 100 \mathrm{~g}$. Samples from Nachna, Jaisalmer were found superior because of high nutritional value.
\end{abstract}

Copy Right, IJAR, 2018. All rights reserved..

\section{Introduction:-}

Calligonum polygonoides is a small shrub belonging to family Polygonaceae found in Thar desert areas, usually 4 feet to 6 feet high but occasionally may reach even 10 feet in height. It is the most common perennial shrub widely present in some localities of Thar Desert. It is a rigid , frost hardy much branched almost leafless typical sand dune shrub, growing on dry sandy soils and bare sand dunes of the desert often covering the entire area. It produces root suckers and is easily propagated by cutting and layering. The young branches are green and fleshy and appear during July to September. During the month of February and March its buds known as Lasson are used by the local population with butter milk and salt (Bhandari, 1990). The plant is fed to cattle. (Kumar et al, 2015). Flowers are believed to contain high amount of protein.

Calligonum polygonoides is becoming increasingly rare due to the demand for its roots, which are used to make charcoal. Overgrazing and sand mining are also having an effect. Its charcoal is used to melt iron. The plant has been quoted in Red Data Book of IUCN as endangered plant species due to its large scale exploitation (Singh, 2004).

Many medicinal properties have also been reported in the plant. Extract of the $C$. polygonoides is used for the treatment of typhoid. Decoction is used for the treatment of sore gums. Aqueous paste of the plant is given in opium toxicity because of its emetic property. Flower buds are effective in sun stroke. Flowers are also used for the treatment of asthma, eczema, cough and cold. It is reported that juice of the plant is applied in eyes to remove poisonous effect of Calotropis procera (Kapoor \& Kumar, 2013). It is reported that plant possessed antioxidant and antifungal properties (Khan et al, 2015). Singh et al (2004) have described the ethnic uses and potentials, as well as 
the need for germplasm conservation of phog (Calligonum polygonoides) for a diverse range of habitats in Rajasthan, India. The possible ways of utilization of phog are described in terms of: food value; fodder value; medicinal value; fuelwood; agricultural uses; live hedge; social and religious aspects; material for huts; and for rehabilitation of degraded lands.

Flowers are believed to be very nutritious and contain high amount of protein. Hence nutritional evaluation of flowers from different regions of Rajasthan was taken up so as to determine the superior chemotype in terms of its food value. There are few reports on nutrional value of Calligonum but its variation from different areas has not been studied so far.

\section{Materials \&Methods:-}

Reconaissance survey was carried out in various parts of Rajasthan and on interaction with local people, forest Department officials, University professors and places for collection of selected plants were identified. Flower buds were collected from three places : Bikaner, Barmer, and Nachna (Jaisalmer). Buds were washed with water to remove dirt and foreign materials and dried in shade. Finally these were ground, and stored in labelled air tight containers for further use.

Nutritional Analysis:-

All the chemicals used in the study were of analytical grade and procured from Merck. The standards were procured from SIGMA.

\section{Proximate analysis:-}

Moisture, ash, total dietary fibre (TDF), crude protein, sugar (TSS) and fat were analyzed by the methods described in AOAC (1995). Moisture was determined by drying a representative $2 \mathrm{~g}$ sample in an oven with air circulation at $60-80^{\circ} \mathrm{C}$ for $3 \mathrm{~h}$. Ash content was determined by the incineration of sample in a muffle furnace at $600^{\circ} \mathrm{C}$ for $6 \mathrm{~h}$ until the ash turned white. Total Dietary fibre determined by assay kit (SIGMA). It is a combination of enzymatic and gravimetric methods. Samples were gelatinized with heat stable $\alpha$-amylase and then enzymatically digested with protease and amyloglucosidase to remove the protein and starch present in the sample. Ethanol is added to precipitate the soluble dietary fibre.Crude protein was estimated by the Kjeldahl method. Total protein was calculated by multiplying the evaluated nitrogen by 6.25 . Fat was determined by petroleum ether extraction in a Soxhlet apparatus. Total Sugar content was estimated by phenol-sulphuric acid method.

\section{Mineral Analysis:-}

Mineral element $(\mathrm{Cu}, \mathrm{Zn}, \mathrm{Fe}, \mathrm{Mn}, \mathrm{Mg})$ contents were determined by wet digestion methods using Atomic Absorption Spectrophotometer (AAS, Perkin Elmer) An acid digestion procedure was used for sample preparation. A weighed amount of plant material were placed in a digestion tubes (Kjeldahl flasks) and a mixture of $\mathrm{HNO}_{3}$ and $70 \% \mathrm{HClO}_{4}$ was added to each sample and then mixture was heated slowly at a low temperature. After digestion, the samples were diluted to the appropriate volume with deionised water and determined the concentration of the elements of interest. Standards prepared by suitable dilution of the stock standard solutions for each element. K, Ca \& Na were estimated by flame photometer (Systronics). Selenium was estimated by ICPMS (Thermofischer).

Results \& Discussion:-

Nutritional evaluation of Calligonum polygonoides flower buds:-

\begin{tabular}{|l|l|l|l|}
\hline Table 1: Variation of Moisture content (\%) and Morphological Parameters \\
\hline Region & Barmer & Bikaner & Jaisalmer \\
\hline Moisture (\%) & 59.9 & 62.7 & 62.8 \\
\hline Av.Wt of 50 buds (g) & 0.4162 & 0.534 & 0.501 \\
\hline
\end{tabular}

Table 2:-Variation of Ash content (\%)

\begin{tabular}{|l|c|c|c|}
\hline Year\Region & Bikaner & Barmer & Nachna \\
\hline $\mathbf{2 0 1 2}$ & 12.9 & 13.4 & 15.0 \\
\hline $\mathbf{2 0 1 3}$ & 7.06 & 11.55 & 11.8 \\
\hline $\mathbf{2 0 1 4}$ & 8.8 & 9.6 & 10.2 \\
\hline Mean \pm SE & $9.58 \pm 1.73$ & $11.51 \pm 1.09$ & $12.33 \pm 1.41$ \\
\hline
\end{tabular}


Table 3:-Variation of Fat content $(\%)$

\begin{tabular}{|l|c|c|c|}
\hline YearlRegion & Bikaner & Barmer & Nachna \\
\hline $\mathbf{2 0 1 2}$ & 1.2 & 1.6 & 0.88 \\
\hline $\mathbf{2 0 1 3}$ & 1.4 & 1.9 & 0.78 \\
\hline $\mathbf{2 0 1 4}$ & 1.3 & 1.86 & 0.56 \\
\hline Mean \pm SE & $1.3 \pm 0.05$ & $1.78 \pm 0.09$ & $0.74 \pm 0.09$ \\
\hline
\end{tabular}

Table 4:-Variation of Sugar content (\%)

\begin{tabular}{|l|c|c|c|}
\hline YearlRegion & Bikaner & Barmer & Nachna \\
\hline $\mathbf{2 0 1 2}$ & 10.39 & 11.1 & 11.7 \\
\hline $\mathbf{2 0 1 3}$ & 8.75 & 9.4 & 10.4 \\
\hline $\mathbf{2 0 1 4}$ & 9.59 & 6.79 & 9.7 \\
\hline Mean \pm SE & $9.57 \pm 0.47$ & $9.09 \pm 1.25$ & $10.6 \pm 0.58$ \\
\hline
\end{tabular}

Table 5:-Variation of Protein content (\%)

\begin{tabular}{|l|c|c|c|}
\hline Year\Region & Bikaner & Barmer & Nachna \\
\hline $\mathbf{2 0 1 2}$ & 5.04 & 6.79 & 7.7 \\
\hline $\mathbf{2 0 1 3}$ & 9.3 & 10.5 & 11.7 \\
\hline $\mathbf{2 0 1 4}$ & 6.01 & 6.80 & 8.35 \\
\hline Mean \pm SE & $6.78 \pm 1.28$ & $8.03 \pm 1.23$ & $9.25 \pm 1.23$ \\
\hline
\end{tabular}

Table 6:-Variation of Vitamin C content (mg/100g)

\begin{tabular}{|l|c|c|c|}
\hline YearlRegion & Bikaner & Barmer & Nachna \\
\hline $\mathbf{2 0 1 2}$ & 45.99 & 45.99 & 50.56 \\
\hline $\mathbf{2 0 1 3}$ & 60.27 & 65.75 & 75.35 \\
\hline $\mathbf{2 0 1 4}$ & 86.66 & 76.09 & 94.87 \\
\hline Mean+SE & $64.3 \pm 11.91$ & $62.61 \pm 8.82$ & $73.59 \pm 12.82$ \\
\hline
\end{tabular}

Moisture content varied from 59.9 to $62.85 \%$ (Table 1). Weight of 50 buds was more in samples from Bikaner $(0.534 \mathrm{~g})$. Ash content (Table 2) was found to vary from $7.06 \%$ to $12.9 \%$ in samples from Bikaner, $9.6 \%$ to 13.4 $\%$ in samples from Barmer and $10.2 \%$ to $15 \%$ from Nachna. Maximum mean ash content was obtained in samples from Nachna (12.33\%). Fat content (Table 3) was found to vary from $1.2 \%$ to $1.4 \%$ in samples from Bikaner, 1.6 $\%$ to $1.86 \%$ in samples from Barmer and $0.56 \%$ to $0.88 \%$ from Nachna . Maximum mean fat content was obtained in samples from Barmer (1.78\%). Sugar content (Table 4) was found to vary from $8.75 \%$ to $10.39 \%$ in samples from Bikaner, $6.79 \%$ to $11.1 \%$ in samples from Barmer and 9.7\% to $11.7 \%$ from Nachna. Maximum sugar content was obtained in samples from Nachna (10.6\%).

Protein content (Table 5) varied from 5.04\% to $9.3 \%$ in samples from Bikaner, $6.79 \%$ to $10.5 \%$ in samples from Barmer and $7.7 \%$ to $11.7 \%$ in samples from Nachna. Maximum protein content was higher in samples from Nachna (9.25\%). Vitamin C content (Table 6) was found to vary from $45.99 \%$ to $86.66 \%$ in samples from Bikaner, $45.99 \%$ to $76.09 \%$ in samples from Barmer and $50.56 \%$ to $94.87 \%$ from Nachna . Maximum Vitamin C content was obtained in samples from Nachna $(73.59 \%)$.

Table 7:-Mineral content in Calligonum polygonoides flower buds

\begin{tabular}{|c|c|c|c|c|c|c|c|c|c|}
\hline & $\begin{array}{l}\mathrm{Cu} \\
\mathrm{mg} / 100 \mathrm{~g}\end{array}$ & $\begin{array}{l}\mathrm{Zn} \\
\mathrm{mg} / 100 \mathrm{~g}\end{array}$ & Fe mg/100 & $\begin{array}{l}\text { Mn } \\
\mathrm{mg} / 100 \mathrm{~g}\end{array}$ & $\begin{array}{l}\mathrm{Mg} \\
\mathrm{mg} / 100 \mathrm{~g}\end{array}$ & P mg/100 & $\begin{array}{l}\mathrm{K} \\
\mathrm{g} / 100 \mathrm{~g}\end{array}$ & $\begin{array}{l}\mathrm{Ca} \\
\mathrm{g} / 100 \mathrm{~g}\end{array}$ & $\begin{array}{l}\mathrm{Na} \\
\mathrm{g} / 100 \mathrm{~g}\end{array}$ \\
\hline Nachna & 1.8 & 3.1 & 45.8 & 6.0 & 250 & 0.99 & 2.28 & 0.65 & 0.08 \\
\hline Bikaner & 1.5 & 2.9 & 41.2 & 1.3 & 224.3 & 0.72 & 1.16 & 0.19 & 0.02 \\
\hline Barmer & 1.4 & 0.9 & 23.8 & 5.9 & 228 & 0.94 & 1.67 & 0.72 & 0.05 \\
\hline
\end{tabular}

The mineral content (Table 7) was high in Calligonum polygonoides buds collected from Nachna which shows that this region is more saline as compared to other regions. Vyas et al (2012) evaluated the diversity present among 54 wild Calligonum polygonoides plants, sampled from eight different locations within the Thar Desert. The analysis of various chemical and mineral constituents revealed that phog is an excellent source of calcium, potassium and phosphorous while relatively poor in zinc. Among minerals, average potassium content was found maximum $(2$ 
$430 \mathrm{mg} / 100 \mathrm{~g}$ ) with $0.14 \mathrm{CV}$. Zinc was observed comparably less in quantity while highest variable with CV 0.73 (Vyas et al, 2012). In our case zinc content varied from 0.9 to $3.1 \mathrm{mg} / 100 \mathrm{~g}$.

Fruits from forest are an example of foods that together provide more than the recommended amount of fibre $30 \mathrm{~g}$ a day (measured by the AOAC method) for adults over a day. Our results showed that DF content present in Calligonum polygonoides buds was high (41.46-47.91\%).

In Calligonum polygonoides flower buds maximum ash content (12.33\%), sugar content (10.6\%), protein content $(9.25 \%)$ and Vitamin C $(73.59 \mathrm{mg} / 100 \mathrm{~g})$ was obtained in samples from Nachna. Maximum fat content was obtained in samples from Barmer (1.78\%). Hence samples from Nachna, Jaisalmer were found better because of high ash, sugar, protein and Vitamin C. The average nutritional content in case of Calligonum polygonoides was as follows: ash $11.14 \%$, DF $44.98 \%$, fat $1.27 \%$, sugar $9.75 \%$, protein $8.02 \%$ and vitamin C $66.88 \mathrm{mg} / 100 \mathrm{~g}$. Nutritive value of shoots and seeds of Calligonum polygonoides have been determined by Bishnoi \& Gautam, 1991.Crude protein content was more than the shoots $(6.41 \%)$ but less than the seeds $(12.9 \%)$.

\section{Conclusion:-}

Indigenous wild edible species are important traditional sources of fruits and leafy vegetables. Apart from having edible value they are valuable in several other ways pertaining to social, economic and ecological services. These species are free and easy to access for the local communities. Fruiting of Calligonum polygonoides occurs during March in dry season to middle of rainy season which coincides with time of staple food scarcity. The average nutritional content in case of Calligonum polygonoides was determined: ash,11.14 \%, DF, $44.98 \%$, fat, $1.27 \%$, sugar, 9.75\%, protein, $8.02 \%$ and vitamin C, $66.88 \mathrm{mg} / 100 \mathrm{~g}$. Samples from Nachna (Jaisalmer) were found to be better as compared to those from Barmer and Bikaner. Although, the current level of consumption is low and but it can play significant role in the diets of the natives. So efforts should be made to conserve this species and also propagation and cultivation practices should be developed.

\section{References:-}

1. AOAC, 1995. Official methods of analysis of the association of official analytical chemists, Washington D.C., USA.

2. Bhandari, M. M. 1990. Flora of Indian Desert. Scientific Publishers, Jodhpur.

3. Bishnoi S. and Gautam D.D.1991.The Reproductive Capacity and Nutritive Value of Calligonum polygonoides Linn. Annals of Arid Zone 30 (2):139-144.

4. Kumar, T.P., Indira, V. and Sankar, M. 2015. Nutritional Evaluation of Wild Leafy Vegetables Consumed by Tribals in the Wayanad District of Kerala. InProceedings of the National Academy of Sciences, India Section B: Biological Sciences. 85 (1): 93-99.

5. Kapoor, B. B. S. and Kumar, S. 2013. Ethnomedicinal Plants of Barmer District, Rajasthan Used In Herbal And Folk Remedies. Indian Journal of Pharmaceutical and Biological Research, 1( 3): 61-66.

6. Khan, A., Khan, R. A., Ahmed, M., and Mushtaq, N. 2015. In Vitro Antioxidant, Antifungal And Cytotoxic Activity of Methanolic Extract of Calligonum Polygonoides. Bangladesh Journal of Pharmacology, 10(2) : 316320.

7. Singh, A.K. 2004. Endangered economic species of Indian desert. Gen. Res. Crop Evol. 51: 371-380.

8. Singh J.P., Beniwal R.K., Soni M.L. and Mondal B.C., 2004. Ethnic uses of Phog (Calligonum polygonoides L.) and its germplasm conservation. Range Management and Agroforestry. 25(1):43-47.

9. Vyas G.K., Kumar V., Sharma R., Sharma R.A., Sharma S., Singh J.P. \& Kumar S.2012. Chemical and genetic diversity among some wild stands of Calligonum polygonoides (Polygonaceae) from the Thar Desert of Rajasthan Rev. biol. trop .60(3) : 1097-1108 . 